\title{
Mezirowin itseohjautuvuuskäsityksiä ymmärrettävästi
}

\section{Leena Ahteenmäki-Pelko- nen (1997). Kriittinen näkemys itseohjautuvuu- desta. Systemaattinen analyysi Jack Mezirowin itseohjautuvuuskäsityksis- tä. Väitöskirjatutkimus. Helsingin yliopiston kasvatustieteen laitoksen tutkimuksia 157, 1997.}

A merikkalainen aikuiskasvaA tustieteen professorin Jack M ezirowin kehittämä aikuisten oppimista ja kehittymistä kriittisen tiedostamisen kautta kuvaava käsitteistö on ollut parin vuosikymmenen ajan keskustelun kohteena sekä kansainvälisesti että kansallisesti. M uutosteoriaksi kutsuttu lähestymistapa onkin empiiristä tutkimusta ja käytännön sovelluksia enemmän johtanut teoreettisiin pohdintoihin. Jatkuvaa reflektiivista omien ajattelu- ja toimintatapojen pohdintaa voidaan pitää 'postmodernin' aikuisen perustaitona, ja vaikka sosiologien viljelemää muotitermiä vieras- taisikin, asettavat muuttuneet työ elämän ja aikuiskoulutuksen käytännöt näitä vaatimuksia joka tapauksessa. Perinteisiin ja pysyvyyteen ei voi enää luottaa, yksilöstä on tullut oman elämänsä käsikirjoittaja, työelämäsuhdettaan joutuu arvioimaan ja rakentamaan jatkuvasti ja aikuiskoulutuksessakin valta ja vastuu on siirtymässä kiihtyvällä vauhdilla opiskelijoille itselleen.

M ezirowin kaltainen teoreetikko tarjoaa hyviä eväitä sekä aikuisopiskelijoille että kouluttajille sen suhteen, miten ottaa oma elämä haltuun, tehdä tiedostettuja ja perusteltuja valintoja sekä elää onnellinen elämä vaikeissakin tilanteissa ja muuttumattomilta tuntuvien rakenteiden puristuksessa. Ennen kaikkea mezirowilainen lähestymistapa auttaa kehittämään uudenlaisia opiskeluympäristöjä, joissa opiskelijoilla itsellään on todelliset välineet 'itseohjattujen' opiskeluprosessien suunnitteluun ja toteutukseen (kts. Man- ninen 1996, 95-98). M yös yrityssektorilla voidaan ennustaa, että ensimmäinen Mezirowin ajatukset todesta ottava yritys astuu aimo askeleen kohti todellista oppivaa organisaatiota.

M ezirowin ajatusten leviä1 misen hidasteena, ellei suorastaan esteenä, on ollut niiden esittäjän käsitteellisesti ja teoreettisesti vaikeaselkoinen käsittelytapa, jota Mezirowin kirjasta vuonna 1995 tehty suomennos ei ole helpottanut lainkaan. Moni aikuiskouluttaja on luopunut ymmärtämisen yrittämisestä tai hahmottanut vain osittain Mezirowin takaa-ajaman ajatusmaailman. K uitenkin Mezirowin ajatusten hedelmällisyys ja toimivuus näkyy päivittäin kaikessa aikuiskoulutustoiminnassa, jos osaa katsoa ja tulkita.

Tätä taustaa vasten on Leena A hteenmäki-Pelkosen tuore väitöskirja tervetullut jäsennys ja koonta Mezirowin teoriasta. 
M ezirowin tekstien systemaattisen analyysin avulla on tutkimuksessa luotu kokonaiskuva M ezirowin itseohjautuvuuskäsityksistä sekä niiden suhteesta kokonaisteoriaan. Vaikeaselkoinen käsitteistö ja ajattelumalli on kääntynyt Ahteenmäki-Pelkosen tutkimuksessa lähes mestarimaisesti ymmärrettäväksi suomeksi, ja kirjan kautta hahmottuu yllättävän koherentti M ezirowin muutosteoria - huomattavasti selkeämmin kuin teorian kehittäjä itse on koskaan esittänyt tai tulee todennäköisesti esittämään. Itse asiassa Mezirowin teoriaan olisikin viisainta tutustua juuri tämän tutkimuksen kautta, ennen kuin menee alkuperäisten lähteiden äärelle.

Vaikka kyseinen väitös onkin sinnikkään tutkijan yksilösuoritus, se istuu hyvin $\mathrm{Helsingin} \mathrm{yli-}$ opiston kasvatustieteen laitoksen tutkimuslinjoihin, joiden käsiteanalyyttistä juonnetta ovat kulkeneet Peep Koort, Singa Sandelin ja Seppo Kontiainen. Laitoksella on myös tehty aikuiskasvatuksen keskeisten ajattelijoiden teorioiden analyysia (K nowlesista Manninen $\&$ al 1988) ja nyt Mezirowista. Väitöksen taustalla on myös systemaattisen analyysin menetelmäkehitys, joka on kulkenut rinnan tutkijan toisen taustatieteen, teologian kanssa.

Tutkijan jäsennys Mezirowin kriittisistä itseohjautuvuusnäkemyksistä on erinomainen lisä itseohjautuvuuskeskusteluun (toinen vastaava on Pasasen, 1998, tuore analyysi refleksiivisen itseohjautuvuuskäsityksen mahdollisuuksista), joka on pääosin ohjautunut naivin humanistisista lähtökohdista pai- nottaen didaktista itseohjautuvuutta, aikuisen oletettua kykyä (ja halua) tehdä omaan opiskeIuun liittyviä päätöksiä ja valintoja. Perinteisten omien koulutustarpeiden arviointikyvyn ja itsearvioinnin rinnalle (tai oikeammin taustalle) nousevat Mezirowin teoriasta itseohjautuvuuden avainkäsitteiksi tiedostaminen, kommunikatiivisuus ja intentionaalisuus, joiden kokoavana yläkäsitteenä on yksilön muutosvalmius. N ämäkin termit saavat ymmärrettävän selityksen ja merkityksen tutkijan tekstin kautta, analyysin etenemistä seurattaessa.

$T$ utkimuksessa on kolme tutkimusongelmaa; (1) miten Mezirow määrittelee aikuisopiskelijan itseohjautuvuuden merkityssisällön, (2) miten itseohjautuvuutta koskevat käsitykset sijoittuvat Mezirowin [uudistavan oppimisen] teorian kokonaisuuteen, sekä (3) miten M ezirowin käsitykset suhteutuvat aikaisempiin näkemyksiin ja keskusteluun itseohjautuvuudesta. $\mathrm{K}$ ahteen ensimmäiseen ongelmaan vastaaminen muodostaa väitöskirjan vahvan rungon; systemaattisen M ezirowin tekstien analyysin kautta jäsentyvät $\mathrm{Me}$ zirowin ajattelun ydinkäsitteet ja niiden väliset suhteet, ja samalla hahmottuu mielenkiintoinen aikuisen kehittymisen teoria, jolla on myös käytännön relevanssia erityisesti vaikeissa muutosja kriisitilanteissa elävien inmisten selviytymisen kannalta, mutta myös arkipäivän tilanteissa, jos halutaan ymmärtää miten suuri merkitys itse asiassa on opituilla ja tiedostamattomilla ajattelu-, toiminta- ja reago intimalleilla, jotka sanelevat itse kunkin elämää. Tutkija toteaa (s.
271) että systemaattisen analyysin tehtävä on tehdä alkuperäisiä tekstejä ymmärrettävämmäksi, ja juuri tässä kohdin tutkimus on erinomaisen ansiokas. Tutkimusongelmaan numero kolme vastaaminen ei yllä samalle tasolle, ja - kuten tutkija toteaakin - se olisi myös vaatinut muiden vertailtavien teorioiden (Tough, Freire, K nowles) yhtä systemaattista analyysia kuin on tehty Mezirowin kohdalla. Toughin oppimisprojektiteemaa ei tosin voi pitää teoriana, eikä K nowleskaan ole teoria saati tasaveroinen haastaja M ezirowille. K nowlesista on toisaalta jo tehty varsin valmiiksi kaluttu analyysi (Manninen \& al. 1988), johon tutkija kuitenkin viittaa vain paikoitellen vaikka se onkin ollut selvästi materiaalina analyysin edetessä. Vertailu mainittuihin kirjoittajiin on siten varsin keveää eivätkä tulokset tuo juurikaan uutta esille. Myös tietty lukeneisuuden puute paistaa läpi siinä, että kirjallisuudesta olisi löytynyt varsin helposti vertailua jäsentäviä tekstejä (esimerkiksi Tennantin, 1988, vertailu Mezirowin ja K nowlesin lähestymistavoista, jota ei löydy lähdeluettelosta; jäsennyksiä ko. lähestymistavoista ja itseohjautuvuudesta olisi löytynyt myös hyvin läheltä eli tutkijakollegoiden kirjoituksista, esimerkiksi Manninen 1993 ja 1996).

Sama häivähdys lukeneisuuden puutteista näkyy muuallakin. Kotimaisten itseohjautuvuustutkijoiden Mezirowin käyttämättömyyden ja empiirisen itseohjautuvuustutkimuksen esimerkkinä esitetään 1989 julkaistu gradu ja sen pohjalta tehty kirja, ja uusin lähteenä käytetty 
empiirinen tutkimus (K oron väitöskirja, johon viitataan kahdesti ohimennen) on vuodelta 1993. K nowlesin ja andragogiikan käsittelyssä on havaittavissa parissa kohtaa pohdiskelua, josta käy ilmi, ettei kirjoittaja ole täysin selvillä ko. käsitteen historiasta ja merkityssisältöjen vaihtelusta, vaikka tämä olisi helposti korjaantunut omankin laitoksen julkaisuihin perehtymällä ( $M$ anninen \& al. 1988).

A merikkalainen itseohjautuvuus-keskustelu 'henkilöidään' H uey Longiin ja O klahomassa 1990-92 pidetyistä konferensseista tehtyihin artikkelikokoelmiin, ja perustellaan Mezirowin 'toisinajattelijan' roolia sillä, ettei häntä ole ko. konferenssissa näkynyt; koulukuntien ja taustojen parempi tuntemus olisi paljastanut, että ko. konferenssin osanottajat ja Mezirow ovat varsin selkeästi eri planeetalta. O lisi ollut hyvin yllättävää jos Mezirow olisi osallistunut esimerkiksi vuoden 1991 konferenssiin, jonka päähenkilöinä paistattelivat Malcolm K nowles ja Lucy Guglielmino, joista Mezirow on tietoisesti halunnut ottaa etäisyyttä teoriansa kehitteIyn avulla. Miksi ateisti osallistuisi lestadiolaisten herätyskokouksiin?

$\mathrm{L}$ ukija jää kaipaamaan tutkijan aiemmin $\mathrm{mm}$. lisensiaattityössään ja sen tarkastuksen yhteydessä esittämiä teoriaa jäsentäviä erinomaisia kaavioita ja malleja, jotka väitöskirjasta puuttuvat täysin. Tosin erinomaisen luettava ja mukava teksti pitää lukijan mielenkiinnon yllä muutenkin, mutta monimutkaisen teorian ja käsiteavaruuden jäsentäjinä ne olisivat olleet paikallaan. A nalyysia haittaa muutamien englanninkielisten termien käännöksiin liittyvät ongelmat, joista vastaväittäjän esille nostaman seff-de ception itsehalveksunta -parin lisäksi mainittakoon esimerkiksi adult education -termin kääntäminen aikuiskoulutukseksi (s. 149); aikuiskasvatus olisi laajempana ollut paljon kuvaavampi ja lähempänä sitä merkitystä, jonka Mezirow haluaa sille antaa. Sanakirjan kanssa käännettäessä syntyy aina käännösongelmia, joista muutamat (esimeriksi s. 207 'inasmuch as') johtavat tutkijan tekemään spekulatiivisia ja vaihtoehtoisia tulkintoja; lauseyhteydestä ja sävyeroista pääteltävät merkitykset olisi ollut helppo tarkistaa englantia äidinkielenään puhuvalta henkilöltä.

$\mathrm{H}$ armittavinta on, ettei väitöskirjaa julkaistu englanniksi. Mikä olisi ollut hedelmällisempi tilanne kuin Jack Mezirow vastaväittäjänä? Tutkimuksen pohjalta tulisi ehdottomasti tuottaa pikaisesti englanninkielisiä artikkeleita kansainväliseen levitykseen, koska tämäntyyppisellä tutkimuksella on suuri kysyntä ja A hteenmäki-Pelkosen analyysi edustaa ehdotonta kansainvälistä kärkeä tällä alueella. Lähdeluettelon mukaan tutkijalta on ilmestynyt vain yksi englanninkielinen artikkeli vuonna 1994, sekin pienilevikkisessä pohjoismaisessa julkaisussa ja tutkijakollegoiden talkookäännöksenä. K ieliongelmat, käännöskustannukset ja arkuus tarjota artikkeleita kansainväliseen levitykseen ovat suurimmat suomalaisten tutkijoiden ongelmat, ei suinkaan tutkimuksen taso, mikä näkyy erinomaisesti tämän tutkimuksen kohdalla. Pitäisikö yliopistoihin perustaa käännös- asiamiehen virkoja?

E rityinen kiitos tutkijalle kuuluu terminologiavalinnasta, eli itseohjatun oppimisen käyttämisestä omituisen 'itseohjautuvan' oppimisen sijasta (opiskelija on subjekti, ei oppiminen; vrt. 'itseohjattu vs. itseohjautuva auto'). K un vielä me aikuiskasvatustieteilijät oppisimme puhumaan opiskelusta ja oppimisesta oikeilla käsitteillä, voisimme joskus päästä puhumaan samaa kieltä oppimisen tutkimusta tekevien psykologien kanssa.

\section{Viittakset}

MAN N INEN, J. \& K auppi, A.\& Kontiainen, A. (1988). K oulutussuunnittelun lähtökohtia - analyysi K nowlesin andragogiikasta didaktisena lähestymistapana. H elsingin yliopisto, kasvatustieteen laitos, tutkimuksia 116.

MAN N I NEN , 」. (1993). Muutoksen suunnittelu yksilötasolla. Teoksessa: S. K ontiainen \& K. N urmi (toim.) Muutos ja interventio. Helsingin yliopisto, kasvatustieteen laitos, Tutkimuksia 139. ss. $87-107$.

MAN N I N E N, J. (1996). K adonneen aarteen metsästäjät? A kateemisille työnhakijoille tarkoitettujen yksilöllisten täydennyskoulutusohjelmien vaikuttavuus. H elsinki: Lahden tutkimus- ja koulutuskeskus.

PASANE N, H. (1998). Refleksiivisen itseohjautuvuuskäsityksen hahmotusta. Teoksessa: Manninen, J. 1998 (toim.) Aikuiskoulutus modernin murroksessa. $N$ äkökulmia työllistymistä edistävän koulutuksen ja ohjauksen merkityksiin ja vaikuttavuuteen. H elsingin yliopiston kasvatustieteen laitoksen tutkimuksia 158

TEN N ANT, M. (1988) Psychology and adult learning. London: Routledge.

Jyri Manninen

AIKUISKASVATUS 1/98 